\title{
Livestock Husbandry in Devi Patan Plain, Uttar Pradesh: A Geographical Study
}

\author{
Zafar Tabrez', Nizamuddin Khan ${ }^{2}$ \\ Department of Geography, Aligarh Muslim University, Aligarh, 202002. INDIA.
}

\begin{abstract}
Livestock husbandry is an important agriculture sub-sector of Indian economy. It significantly contributes to the agricultural GDP in India. Livestock farming, however, has been appearing one of the most important value added farming system adopted in the country. Livestock products also play a main role in export earnings. After cultivation of crops, livestock is the second largest productive asset in rural India. India's livestock sector is one of the largest in the world. In 2010-11, livestock generated outputs worth Rs 2075 billion (at 2004-05 prices) which comprised 4 per cent of the GDP and 26 per cent of the agricultural GDP. Livestock husbandry is well developed in Western Trans-Ghaghara (Devi Patan) plain, Uttar Pradesh. The plain of Devi Patan includes the districts of Bahraich, Gonda, Balrampur, And Shrawasti districts. In Devi Patan plain, more than 70 per cent of rural household are directly or indirectly engaged with livestock husbandry. The result obtained with the application of statistical technique shows that in all the 44 blocks of Devi Patan plain, there is a huge spatial variation of animals like buffalo, cattle, sheep and goat in all the blocks.
\end{abstract}

Keywords: dairy products, farming system, livestock, productivity, technological development.

\section{Introduction}

Livestock husbandry is an important agriculture sub-sector of Indian economy. It significantly contributes to the agricultural GDP in India. (Iqubal, A., 2013). It is the most important source of food security as it provides meat and milk and other dairy products, which enrich the nutrition intake. (Khan, N., Khan, M. M. and Rehman, A., 2009). Livestock constituted the oldest wealth resource of mankind and was taken as symbol of economic status in the society. (Khan, N., \& Iqubal, M.A., 2011). In the absence of fertile lands and assured irrigation which are controlled by a small population of rich farmers and lack of employment in the industrial and service sectors, most of the rural families belonging to socio- economically weaker sections of the society maintain different species of livestock to supplement their income. (Hegde, N.G., 2006). When abundant feed is available, livestock can be considered a form of wealth, power and security, a perception based on the conversion of solar energy captured in biomass into products valuable for human society (Schiere, J.B., 2002). Livestock sector is expected to emerge as an engine of agricultural growth in the 12th plan and beyond in view of rapid growth in demand for animal food products. Achieving growth rate of 5-6\%, however, would require addressing challenges of shortage of feed and fodder and frequent occurrence of some deadly diseases.

Livestock is an important source of income and employment in rural areas. It provides balanced nutrition in the form of milk, egg and meat besides farm power. Animal husbandry plays a major role in providing employment especially self employment with high participation of women. The increase in the demand and supply of livestock and livestock products rose up exorbitantly at global level as a sequel to increasing urbanization, burgeoning population growth as also improved income levels, changing lifestyles and consumption of high calorie food. Various kinds of livestock species like cattle, buffalo, goat, sheep, hen and pig etc. were reared as domestic and subsistence animals. (Khan, N., 2012). There are various ways in which livestock husbandry is being practiced viz; mixed farming, nomadic herding, and commercial grazing and so on. Livestock rearing incorporates not only keeping the animals and feeding them, but it also includes the marketing of animals, animal rearing and collecting and processing milk or milk products for marketing them to get maximum remunerations. (Khan, N., Rehman, A. and Salman, M.S., 2013). India has huge population of different species of livestock. In 2007 there were 199 million cattle, 105 million buffaloes, 72 million sheep, 141 million goats, 11 million pigs and 649 million poultry birds. The cattle population after reaching a peak of 204.6 million in 1992 declined until 2003, but again showed an increasing trend in 2007. The decline in cattle number was largely confined to the male cattle - an important source of draught power in Indian agriculture. Their number declined from 101 million in 1992 to around 83 million in 2007. This was due to declining size of land holding and increasing mechanization of agricultural operations.

Livestock husbandry is well developed in Western Trans-Ghaghara (Devi Patan) plain, Uttar Pradesh. The plain of Devi Patan includes the districts of Bahraich, Gonda, Balrampur, And Shrawasti districts. In Devi Patan plain, more than 70 per cent of rural household are directly or indirectly engaged with livestock husbandry. The result obtained with the application of statistical technique shows that in all the 44 blocks of Devi Patan plain, there is a huge spatial variation of animals like buffalo, cattle, sheep and goat in all the blocks. 


\section{Objectives}

The present paper attempts to analyze the distribution and growth of livestock husbandry at the block level in Western Trans-Ghaghara (Devi Patan) Plain. In the study area the spatial distribution of livestock not only includes the total livestock at different blocks but also the distribution of different species i.e. Cattle, Buffalo, Sheep and Goat among different blocks of Devi Patan Plain, Uttar Pradesh.

\section{Database And Methodology}

The present study is based on the secondary sources of data. Broadly, four species namely, Cattle, Buffalo, Sheep and Goat have been taken into consideration as livestock species in the study area. The data of total livestock population, species wise livestock population in the study area to calculate the total block wise distribution of total livestock, species wise percentage of livestock, and decadal growth have been obtained from the Statistical bulletin and Statistical offices of the districts of Bahraich, Balrampur, Gonda and Shrawasti of the year 1997 and 2007.

\section{The Study Area}

In 2011 India has 121, 01, 93,422 people, out of which Uttar Pradesh has 19, 95, 81,477 people living in 71 districts. The sex-ratio of Devi Patan plain is about 902. The average literacy rate of Devi Patan plain is $53.28 \%$, which is much below than the average literacy rate of Uttar Pradesh which is $67.68 \%$. In terms of male and female literacy rates of Devi Patan Plain it is $63.41 \%$ and $41.97 \%$ respectively. In terms of district wise sexratio of Devi Patan plain, it is 922 in both Gonda and Balrampur, 891 in Bahraich, and 875 in Shrawasti. The district wise literacy rate of Devi Patan plain is $61.16 \%$ in Gonda, $51.76 \%$ in Balrampur, $51.10 \%$ in Bahraich, and $49.13 \%$ in Shrawasti. Shrawasti is the most backward district of Devi Patan plain in terms of sex-ratio, literacy, male-female literacy differentials, and so on. Devi Patan plain is the most backward region of Uttar Pradesh, which lies at the foothills of the Shiwalik range. Its international boundary touches with Nepal. Its latitudinal extent is $26^{\circ} 40^{\prime} 30^{\prime \prime}$ to $28^{\circ} 24^{\prime} 30^{\prime \prime}$ North and $81^{\circ} 03^{\prime}$ to $82^{\circ} 49^{\prime} \mathrm{E}$ longitude. Its northern boundary touches with Nepal. In the east it touches with Ayodhya city of Faizabad division, and Siddharthnagar, and in the south Barabanki, and Sitapur districts lies. The total geographical area of Devi Patan is 14229 sq.km.

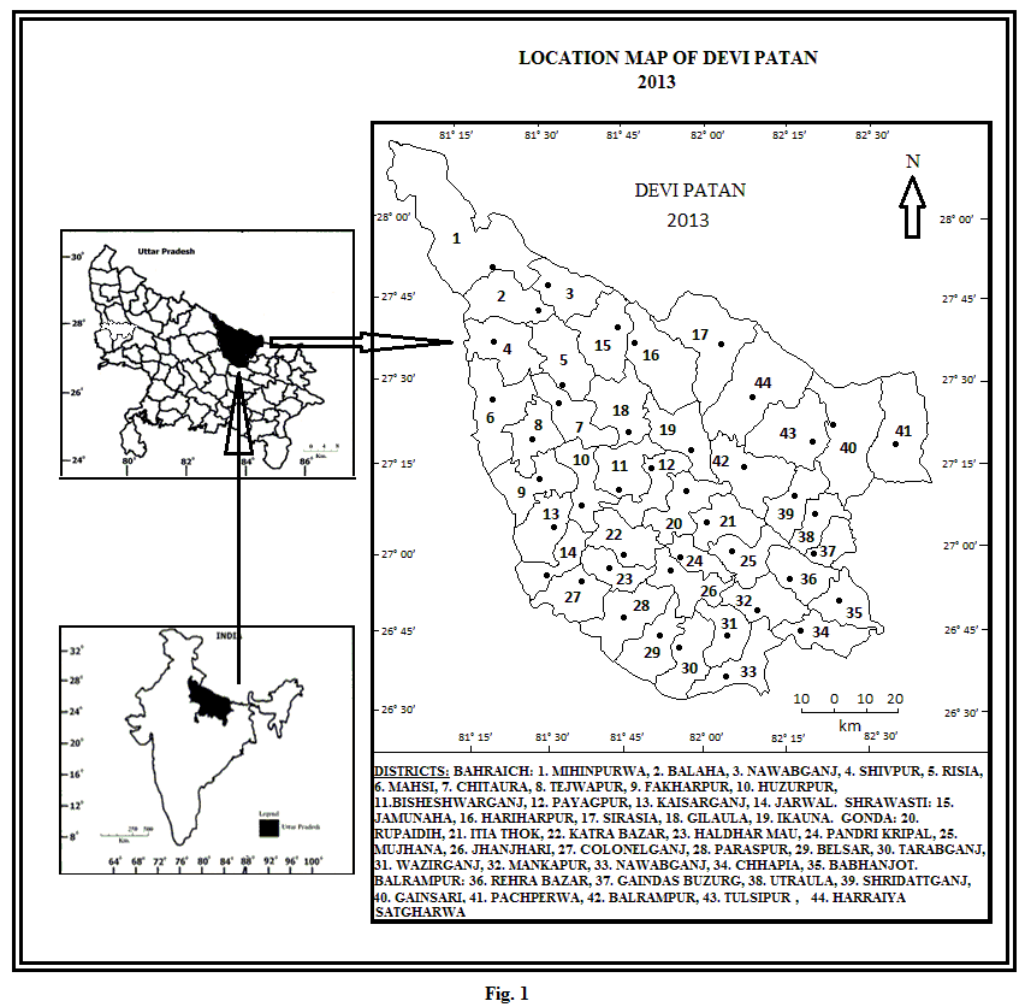

\section{Results And Discussion}

The result obtained from the various studies and methods reveals that Devi-Patan has a large livestock population. The total number of livestock in the region as calculated during 2007-08 was 3268419 heads. In terms of block wise number of livestock it is highest in Chhapia block, where it is 98567 heads, and lowest in Gaindas Buzurg block where it is 35529 heads. There is a great variation among the livestock species i.e. 
Buffalo, Cattle, Sheep and Goat in the study area in terms of their share in total livestock. Buffalo contributes 28.48 percent of the total livestock share, Cattle is at the top, where it contributes 40.79 percent of the total livestock species, Goat share is 29.71 percent, where as sheep are in meagre number where it contributes only 1.02 percent of the total livestock in Devi-Patan plain. The largest share of livestock in the region was found in Chhapia block, where it is 3.02 percent and lowest in Gaindas Buzurg where it is 1.09 percent.

In terms of block-wise distribution of species in Devi-Patan plain, the share of buffalo is highest in Chhapia block where it is 3.61 percent followed by Huzurpur 3.40 percent, and Mankapur 3.39 percent. In terms of lowest share of buffalo in the region, it is lowest in Gaindas Buzurg block where it accounts for only 1.10 percent of the total share of buffalo population. The other blocks of low buffalo population are Shridattganj 1.44 percent, Utraula 1.52 percent and Tulsipur 1.62 percent. In Cattle share, Chhapia block contributes highest of 3.07 percent of total cattle population followed by Balrampur 2.89 percent, and Mankapur 2.86 percent. The blocks which contribute the lowest share of cattle population are Gaindas Buzurg 1.12 percent, Tarabganj 1.44 percent and Belsar 1.53 percent. Sheep contributes a meagre population among all the four livestock species, the share of sheep in the region is highest in Huzurpur where it is 4.60 percent followed by Jarwal and Fakharpur where it is 4.11 and 3.84 percent respectively. In terms of share of goat in the region, it is highest in Mahsi block where it is 3.27 percent followed by Jarwal 3.24 percent and 3.22 percent in Kaisarganj and Nawabganj blocks. The lowest share is recorded in Gaindas Buzurg 1.04 percent, Belsar 1.14 percent and 1.18 percent in Mujhana and Pandri Kripal blocks.

Table 1: Total Livestock in Blocks of Devi-Patan Plain (2007-08)

\begin{tabular}{|c|c|c|c|c|c|}
\hline \multirow[t]{2}{*}{ Blocks } & \multicolumn{5}{|c|}{ Total Livestock } \\
\hline & Number & Percent & Blocks & Number & Percent \\
\hline Mihinpurwa & 87584 & 2.68 & Haldhar Mau & 55225 & 1.69 \\
\hline Balaha & 85931 & 2.63 & Pandri Kripal & 50855 & 1.56 \\
\hline Nawabganj & 87782 & 2.69 & Mujhana & 51602 & 1.58 \\
\hline Shivpur & 83956 & 2.57 & Jhanjhari & 80897 & 2.48 \\
\hline Risia & 85788 & 2.62 & Colonelganj & 64428 & 1.97 \\
\hline Mahsi & 83045 & 2.54 & Paraspur & 55619 & 1.70 \\
\hline Chitaura & 90461 & 2.77 & Belsar & 49488 & 1.51 \\
\hline Tejwapur & 83408 & 2.55 & Tarabganj & 48729 & 1.49 \\
\hline Fakharpur & 83076 & 2.54 & Wazirganj & 58107 & 1.78 \\
\hline Huzurpur & 95031 & 2.91 & Mankapur & 92048 & 2.82 \\
\hline Bisheshwarganj & 85583 & 2.62 & Nawabganj & 63015 & 1.93 \\
\hline Payagpur & 82434 & 2.52 & Chhapia & 98567 & 3.02 \\
\hline Kaisarganj & 90435 & 2.77 & Babhanjot & 82443 & 2.52 \\
\hline Jarwal & 86580 & 2.65 & Rehra Bazar & 63154 & 1.93 \\
\hline Jamunaha & 82344 & 2.52 & Gaindas Buzurg & 35529 & 1.09 \\
\hline Hariharpur & 82274 & 2.52 & Utraula & 59787 & 1.83 \\
\hline Sirasia & 78155 & 2.39 & Shridattganj & 55475 & 1.70 \\
\hline Gilaula & 82304 & 2.52 & Gainsari & 73719 & 2.26 \\
\hline Ikauna & 82344 & 2.52 & Pachperwa & 74199 & 2.27 \\
\hline Rupaidih & 87819 & 2.69 & Balrampur & 80951 & 2.48 \\
\hline Itia thok & 76808 & 2.35 & Tulsipur & 57274 & 1.75 \\
\hline Katra Bazar & 59327 & 1.82 & Harraiya Satgharwa & 74839 & 2.29 \\
\hline Total & & & & 3268419 & 100 \\
\hline
\end{tabular}

Source: Statistical Bulletin and District Handbook of the year 2007.

Table 2: Number of Livestock Species of Various Categories in Devi-Patan Plain (2007-08)

\begin{tabular}{|l|c|c|c|c|c|}
\hline \multirow{2}{*}{ Development Blocks } & \multicolumn{5}{|c|}{ Number of Livestock Species (2007) } \\
\cline { 2 - 6 } & Buffalo & Cattle & Sheep & Goat & Total \\
\hline Mihinpurwa & $23790(2.56)$ & $32669(2.45)$ & $715(2.14)$ & $30410(3.13)$ & $87584(2.68)$ \\
\hline Balaha & $20455(2.20)$ & $35146(2.64)$ & $905(2.71)$ & $29425(3.03)$ & $85931(2.63)$ \\
\hline Nawabganj & $23096(2.48)$ & $32586(2.44)$ & $850(2.55)$ & $31250(3.22)$ & $87782(2.69)$ \\
\hline Shivpur & $19055(2.05)$ & $33181(2.49)$ & $995(2.98)$ & $30725(3.16)$ & $83956(2.57)$ \\
\hline Risia & $20293(2.18)$ & $33875(2.54)$ & $705(2.11)$ & $30915(3.18)$ & $85788(2.62)$ \\
\hline Mahsi & $16440(1.77)$ & $33773(2.53)$ & $1060(3.18)$ & $31772(3.27)$ & $83045(2.54)$ \\
\hline Chitaura & $26172(2.81)$ & $32419(2.43)$ & $820(2.46)$ & $31050(3.20)$ & $90461(2.77)$ \\
\hline
\end{tabular}


Livestock Husbandry in Devi Patan Plain, Uttar Pradesh: A Geographical Study

\begin{tabular}{|c|c|c|c|c|c|}
\hline Tejwapur & $18090(1.94)$ & $33831(2.54)$ & $960(2.88)$ & $30527(3.14)$ & $83408(2.55)$ \\
\hline Fakharpur & $18980(2.04)$ & $32898(2.47)$ & $1281(3.84)$ & $29917(3.08)$ & $83076(2.54)$ \\
\hline Huzurpur & $31678(3.40)$ & $33068(2.48)$ & $1535(4.60)$ & $28750(2.96)$ & $95031(2.91)$ \\
\hline Bisheshwarganj & $20539(2.21)$ & $34659(2.60)$ & $605(1.81)$ & $29780(3.07)$ & $85583(2.62)$ \\
\hline Payagpur & $20015(2.15)$ & $31696(2.38)$ & $735(2.20)$ & $29988(3.09)$ & $82434(2.52)$ \\
\hline Kaisarganj & $23337(2.51)$ & $34590(2.60)$ & $1220(3.66)$ & $31288(3.22)$ & 90435 (2.77) \\
\hline Jarwal & $19859(2.13)$ & $33887(2.54)$ & $1370(4.11)$ & 31464 (3.24) & $86580(2.65)$ \\
\hline Jamunaha & $22682(2.44)$ & $33006(2.48)$ & $909(2.73)$ & $25747(2.65)$ & $82344(2.52)$ \\
\hline Hariharpur & $22612(2.43)$ & $33006(2.48)$ & $909(2.73)$ & $25747(2.65)$ & $82274(2.52)$ \\
\hline Sirasia & $21022(2.26)$ & $31333(2.35)$ & $800(2.40)$ & $25000(2.57)$ & $78155(2.39)$ \\
\hline Gilaula & $22642(2.43)$ & $33006(2.48)$ & $909(2.73)$ & $25747(2.65)$ & $82304(2.52)$ \\
\hline Ikauna & $22682(2.44)$ & $33006(2.48)$ & $909(2.73)$ & $25747(2.65)$ & $82344(2.52)$ \\
\hline Rupaidih & $29994(3.22)$ & $36477(2.74)$ & $639(1.92)$ & $20709(2.13)$ & $87819(2.69)$ \\
\hline Itia thok & $26608(2.86)$ & $31894(2.39)$ & $584(1.75)$ & $17722(1.82)$ & $76808(2.35)$ \\
\hline Katra Bazar & $20911(2.25)$ & $24409(1.83)$ & $571(1.71)$ & $13436(1.38)$ & $59327(1.82)$ \\
\hline Haldhar Mau & $19578(2.10)$ & $22687(1.70)$ & $563(1.69)$ & $12397(1.28)$ & $55225(1.69)$ \\
\hline Pandri Kripal & 18061 (1.94) & $20806(1.56)$ & $525(1.57)$ & $11463(1.18)$ & $50855(1.56)$ \\
\hline Mujhana & $18129(1.95)$ & $21460(1.61)$ & $511(1.53)$ & $11502(1.18)$ & $51602(1.58)$ \\
\hline Jhanjhari & $28313(3.04)$ & $33042(2.48)$ & $651(1.95)$ & $18891(1.95)$ & $80897(2.48)$ \\
\hline Colonelganj & $22822(2.45)$ & $26187(1.96)$ & $684(2.05)$ & $14735(1.52)$ & $64428(1.97)$ \\
\hline Paraspur & $19573(2.10)$ & $22950(1.72)$ & $569(1.71)$ & $12527(1.29)$ & $55619(1.70)$ \\
\hline Belsar & $17511(1.88)$ & $20384(1.53)$ & $495(1.48)$ & $11098(1.14)$ & $49488(1.51)$ \\
\hline Tarabganj & $16368(1.76)$ & $19242(1.44)$ & $508(1.52)$ & $12611(1.30)$ & $48729(1.49)$ \\
\hline Wazirganj & $20759(2.23)$ & $23432(1.76)$ & $610(1.83)$ & $13306(1.37)$ & $58107(1.78)$ \\
\hline Mankapur & $31540(3.39)$ & $38065(2.86)$ & $695(2.08)$ & $21748(2.24)$ & $92048(2.82)$ \\
\hline Nawabganj & $22089(2.37)$ & 25911 (1.94) & $663(1.99)$ & $14352(1.48)$ & $63015(1.93)$ \\
\hline Chhapia & $33644(3.61)$ & $40982(3.07)$ & $768(2.30)$ & $23173(2.39)$ & $98567(3.02)$ \\
\hline Babhanjot & $28716(3.08)$ & $33917(2.54)$ & $659(1.98)$ & $19151(1.97)$ & $82443(2.52)$ \\
\hline Rehra Bazar & 15691 (1.69) & $28929(2.17)$ & $425(1.27)$ & $18109(1.86)$ & 63154 (1.93) \\
\hline Gaindas Buzurg & $10207(1.10)$ & $14906(1.12)$ & $301(0.90)$ & $10115(1.04)$ & $35529(1.09)$ \\
\hline Utraula & $14123(1.52)$ & $27639(2.07)$ & $415(1.24)$ & $17610(1.81)$ & $59787(1.83)$ \\
\hline Shridattganj & $13425(1.44)$ & $24531(1.84)$ & $410(1.23)$ & $17109(1.76)$ & $55475(1.70)$ \\
\hline Gainsari & $18157(1.95)$ & $32504(2.44)$ & $829(2.49)$ & $22229(2.29)$ & $73719(2.26)$ \\
\hline Pachperwa & $18285(1.96)$ & $32729(2.46)$ & $821(2.46)$ & $22364(2.30)$ & $74199(2.27)$ \\
\hline Balrampur & $19376(2.08)$ & $38456(2.89)$ & $920(2.76)$ & $22199(2.29)$ & $80951(2.48)$ \\
\hline Tulsipur & $15115(1.62)$ & $22444(1.68)$ & $514(1.54)$ & $19201(1.98)$ & $57274(1.75)$ \\
\hline Harraiya Satgharwa & $18551(1.99)$ & $37308(2.80)$ & $827(2.48)$ & $18153(1.87)$ & $74839(2.29)$ \\
\hline Total & $930985(100.00)$ & $1332926(100.00)$ & $33349(100.00)$ & $971159(100.00)$ & $\begin{array}{l}3268419 \\
(100.00) \\
\end{array}$ \\
\hline
\end{tabular}

Source: Statistical Bulletin and District Handbook of the year 2007.

\subsection{Growth Of Livestock Husbandry}

The result obtained from the calculations reveals that there is an increase in livestock husbandry from 3105581 heads in 1997-98 to 3268419 heads in 2007-08, a total increase of 162838 heads in Devi-Patan plain. There are both positive and negative growth in the livestock between 1997-08 and 2007-08. In terms of block wise change in the number of livestock, there is a great variation among the blocks. The highest change in the number of livestock is found in Ikauna block where it is 62637 heads of livestocks. The lowest decadal change is found in Mihinpurwa block where growth is negative at -54624 heads. The total growth of livestock is 5.24 percent. In terms of block wise growth of livestock there is a huge variation among the blocks. The highest growth is found in Ikauna where it is 317.84 percent followed by Nawabganj 179.07 percent, Mahsi 130.98 percent and 85.63 percent in Tejwapur block. Majority of the blocks have experienced negative growth. The 
highest negative growth was found in Mihinpurwa where it is -38.41 percent. The other negative growth blocks are Gaindas Buzurg -32.64 percent, Chhapia -17.35 percent, Shridattganj -16.55 percent and -16.17 percent in Jamunaha.

Table 3: Block Wise Change in Number of Livestock in Devi-Patan Plain (1997-98 to 2007-08)

\begin{tabular}{|c|c|c|c|c|}
\hline \multirow[t]{2}{*}{ Development Blocks } & \multicolumn{2}{|c|}{ Total Livestock } & \multicolumn{2}{|c|}{ Decadal Change } \\
\hline & $1997-98$ & $2007-08$ & Number & Percentage \\
\hline Mihinpurwa & 142208 & 87584 & -54624 & -38.41 \\
\hline Balaha & 75504 & 85931 & 10427 & 13.81 \\
\hline Nawabganj & 31455 & 87782 & 56327 & 179.07 \\
\hline Shivpur & 87172 & 83956 & -3216 & -3.69 \\
\hline Risia & 69124 & 85788 & 16664 & 24.11 \\
\hline Mahsi & 35954 & 83045 & 47091 & 130.98 \\
\hline Chitaura & 68035 & 90461 & 22426 & 32.96 \\
\hline Tejwapur & 44933 & 83408 & 38475 & 85.63 \\
\hline Fakharpur & 84447 & 83076 & -1371 & -1.62 \\
\hline Huzurpur & 89191 & 95031 & 5840 & 6.55 \\
\hline Bisheshwarganj & 62860 & 85583 & 22723 & 36.15 \\
\hline Payagpur & 56018 & 82434 & 26416 & 47.16 \\
\hline Kaisarganj & 84547 & 90435 & 5888 & 6.96 \\
\hline Jarwal & 98063 & 86580 & -11483 & -11.71 \\
\hline Jamunaha & 98233 & 82344 & -15889 & -16.17 \\
\hline Hariharpur & 62846 & 82274 & 19428 & 30.91 \\
\hline Sirasia & 86904 & 78155 & -8749 & -10.07 \\
\hline Gilaula & 54848 & 82304 & 27456 & 50.06 \\
\hline Ikauna & 19707 & 82344 & 62637 & 317.84 \\
\hline Rupaidih & 102416 & 87819 & -14597 & -14.25 \\
\hline Itia thok & 87187 & 76808 & -10379 & -11.90 \\
\hline Katra Bazar & 65220 & 59327 & -5893 & -9.04 \\
\hline Haldhar Mau & 59905 & 55225 & -4680 & -7.81 \\
\hline Pandri Kripal & 55338 & 50855 & -4483 & -8.10 \\
\hline Mujhana & 55353 & 51602 & -3751 & -6.78 \\
\hline Jhanjhari & 93128 & 80897 & -12231 & -13.13 \\
\hline Colonelganj & 71872 & 64428 & -7444 & -10.36 \\
\hline Paraspur & 60548 & 55619 & -4929 & -8.14 \\
\hline Belsar & 53206 & 49488 & -3718 & -6.99 \\
\hline Tarabganj & 49167 & 48729 & -438 & -0.89 \\
\hline Wazirganj & 64446 & 58107 & -6339 & -9.84 \\
\hline Mankapur & 107714 & 92048 & -15666 & -14.54 \\
\hline Nawabganj & 69762 & 63015 & -6747 & -9.67 \\
\hline Chhapia & 119264 & 98567 & -20697 & -17.35 \\
\hline Babhanjot & 94483 & 82443 & -12040 & -12.74 \\
\hline Rehra Bazar & 49620 & 63154 & 13534 & 27.28 \\
\hline Gaindas Buzurg & 52746 & 35529 & -17217 & -32.64 \\
\hline Utraula & 63943 & 59787 & -4156 & -6.50 \\
\hline Shridattganj & 66475 & 55475 & -11000 & -16.55 \\
\hline Gainsari & 49124 & 73719 & 24595 & 50.07 \\
\hline Pachperwa & 64506 & 74199 & 9693 & 15.03 \\
\hline Balrampur & 65082 & 80951 & 15869 & 24.38 \\
\hline Tulsipur & 64582 & 57274 & -7308 & -11.32 \\
\hline Harraiya Satgharwa & 68445 & 74839 & 6394 & 9.34 \\
\hline Total & 3105581 & 3268419 & 162838 & 5.24 \\
\hline
\end{tabular}

Source: Statistical Bulletin and District Handbook of the year 1997 and 2007. 
Table 4: Species Wise Growth of Livestock in Devi-Patan Plain (1997-98 to 2007-08)

\begin{tabular}{|l|c|c|c|c|}
\hline \multirow{2}{*}{ Livestock Species } & \multicolumn{2}{|c|}{ Number of Livestock Species } & \multirow{2}{*}{ Difference } & Growth (\%) \\
\cline { 2 - 3 } & $1997-98$ & $2007-08$ & & 11.62 \\
\hline Buffalo & 834033 & 930985 & 96952 & -10.58 \\
\hline Cattle & 1490666 & 1332926 & -157740 & -32.31 \\
\hline Sheep & 49270 & 33349 & -15921 & 32.74 \\
\hline Goat & 731612 & 971159 & 239547 & 5.24 \\
\hline Total & 3105581 & 3268419 & 162838 & \\
\hline
\end{tabular}

Source: Statistical Bulletin and District Handbook of the year 1997 and 2007.

\subsection{Growth Of Livestock Species}

The result obtained from the study shows that cattle and sheep are the two species in Devi-Patan plain which shows negative growth during the last decade between 1997-08 and 2007-08, whereas buffalo and goat shows positive growth. The highest growth is found among goat which is 32.74 percent and 11.62 percent in buffalo. On the contrary, sheep experienced the lowest growth of -32.31 percent followed by cattle -10.58 percent. The total growth of livestock during the last decade is 5.24 percent.

The population of buffalo in 1997-08 was 834033 heads which increased to 930985 heads in 2007-08, an increase of 96952 heads during these two points of time. The total growth of buffalo during the last decade was 11.62 percent. There is a huge variation in the growth of buffalo between the blocks. The highest growth of buffalo is recorded in Ikauna block at 336.19 percent, followed by Nawabganj block 190.48 percent, Huzurpur 134.48 percent and Bisheshwarganj 74.25 percent. The lowest growth was recorded in Jamunaha block which is -58.38 percent. The other blocks of low growth are Fakharpur -39.93 percent, Mihinpurwa -36.54 percent, Sirasia -31.92 percent and Shivpur -27.43 percent.

Table 5: Block Wise Growth of Buffalo in Devi-Patan Plain (1997-08 to 2007-08)

\begin{tabular}{|c|c|c|c|c|}
\hline \multirow[t]{2}{*}{ Development Block } & \multicolumn{2}{|c|}{ Number of Buffalo } & \multirow[t]{2}{*}{ Difference } & \multirow[t]{2}{*}{ Growth (in percent) } \\
\hline & $1997-98$ & $2007-08$ & & \\
\hline Mihinpurwa & 37488 & 23790 & -13698 & -36.54 \\
\hline Balaha & 28086 & 20455 & -7631 & -27.17 \\
\hline Nawabganj & 7951 & 23096 & 15145 & 190.48 \\
\hline Shivpur & 26257 & 19055 & -7202 & -27.43 \\
\hline Risia & 16737 & 20293 & 3556 & 21.25 \\
\hline Mahsi & 15643 & 16440 & 797 & 5.09 \\
\hline Chitaura & 15419 & 26172 & 10753 & 69.74 \\
\hline Tejwapur & 16352 & 18090 & 1738 & 10.63 \\
\hline Fakharpur & 31594 & 18980 & -12614 & -39.93 \\
\hline Huzurpur & 13510 & 31678 & 18168 & 134.48 \\
\hline Bisheshwarganj & 11787 & 20539 & 8752 & 74.25 \\
\hline Payagpur & 11969 & 20015 & 8046 & 67.22 \\
\hline Kaisarganj & 14497 & 23337 & 8840 & 60.98 \\
\hline Jarwal & 15655 & 19859 & 4204 & 26.85 \\
\hline Jamunaha & 54501 & 22682 & -31819 & -58.38 \\
\hline Hariharpur & 20676 & 22612 & 1936 & 9.36 \\
\hline Sirasia & 30879 & 21022 & -9857 & -31.92 \\
\hline Gilaula & 13213 & 22642 & 9429 & 71.36 \\
\hline Ikauna & 5200 & 22682 & 17482 & 336.19 \\
\hline Rupaidih & 27285 & 29994 & 2709 & 9.93 \\
\hline Itia thok & 23276 & 26608 & 3332 & 14.32 \\
\hline Katra Bazar & 17407 & 20911 & 3504 & 20.13 \\
\hline Haldhar Mau & 15998 & 19578 & 3580 & 22.38 \\
\hline Pandri Kripal & 14855 & 18061 & 3206 & 21.58 \\
\hline Mujhana & 14849 & 18129 & 3280 & 22.09 \\
\hline Jhanjhari & 24829 & 28313 & 3484 & 14.03 \\
\hline Colonelganj & 19182 & 22822 & 3640 & 18.98 \\
\hline Paraspur & 16154 & 19573 & 3419 & 21.17 \\
\hline Belsar & 14178 & 17511 & 3333 & 23.51 \\
\hline Tarabganj & 13072 & 16368 & 3296 & 25.21 \\
\hline Wazirganj & 17132 & 20759 & 3627 & 21.17 \\
\hline Mankapur & 28692 & 31540 & 2848 & 9.93 \\
\hline Nawabganj & 18546 & 22089 & 3543 & 19.10 \\
\hline Chhapia & 30736 & 33644 & 2908 & 9.46 \\
\hline Babhanjot & 25201 & 28716 & 3515 & 13.95 \\
\hline Rehra Bazar & 12955 & 15691 & 2736 & 21.12 \\
\hline Gaindas Buzurg & 11727 & 10207 & -1520 & -12.96 \\
\hline Utraula & 14750 & 14123 & -627 & -4.25 \\
\hline
\end{tabular}


Livestock Husbandry in Devi Patan Plain, Uttar Pradesh: A Geographical Study

\begin{tabular}{|l|c|c|c|c|}
\hline Shridattganj & 14312 & 13425 & -887 & -6.20 \\
\hline Gainsari & 14296 & 18157 & 3861 & 27.01 \\
\hline Pachperwa & 14030 & 18285 & 4255 & 30.33 \\
\hline Balrampur & 15473 & 19376 & 3903 & 25.22 \\
\hline Tulsipur & 12845 & 15115 & 2270 & 17.67 \\
\hline Harraiya Satgharwa & 14839 & 18551 & 3712 & 25.02 \\
\hline Total & 834033 & 930985 & 96952 & 11.62 \\
\hline
\end{tabular}

Source: Statistical Bulletin and District Handbook of the year 1997 and 2007.

The population of cattle increased from 1490666 heads in 1997-08 to 1332926 heads in 2007-08. The difference in the cattle distribution among the various blocks is more than the difference of buffalo population in Devi-Patan plain. The total growth of cattle during the last decade is -10.58 percent. In terms of block wise growth of cattle in Devi-Patan plain, it is highest in Mahsi which is 904.85 percent followed by Tejwapur 443.47 percent, Nawabganj 236.67 percent and Balaha 63.3 percent. Majority of the blocks have experienced negative growth. The blocks which contribute the lowest growth are Gaindas Buzurg -45.85 percent, Sirasia 41.33 percent, Tulsipur -38.55 percent, Mihinpurwa -38.17 percent and Chhapia -34.13 percent.

In Devi-Patan plain the population of sheep are very less in number as compared to the other three species like buffalo, cattle and goat. Their total number increased from 49270 heads in 1997-08 to 33349 heads in 2007-08. The total growth of sheep during the last decade is -32.31. Except few blocks the majority of the blocks have experienced the negative growth. In terms of block wise growth in Devi Patan plain, the highest growth of sheep is found in Jamunaha block which is 1718 percent followed by Sirasia 459.44 percent, Nawabganj 249.79 percent, Ikauna 234.19 percent and Huzurpur 229.4 percent. The blocks which recorded the low growth of sheep are Mihinpurwa -82.91 percent which is the lowest growth of sheep. Other blocks of low growth of sheep are Gaindas Buzurg -73.83 percent, Chhapia -69.94 percent, Utraula -63.05 percent and Shridattganj -63.62 percent.

Table 6: Block Wise Growth of Cattle in Devi-Patan Plain (1997-98 to 2007-08)

\begin{tabular}{|c|c|c|c|c|}
\hline \multirow[t]{2}{*}{ Development Block } & \multicolumn{2}{|c|}{ Number of Cattle } & \multirow[t]{2}{*}{ Difference } & \multirow[t]{2}{*}{ Growth (in percent) } \\
\hline & $1997-98$ & $2007-08$ & & \\
\hline Mihinpurwa & 52836 & 32669 & -20167 & -38.17 \\
\hline Balaha & 21522 & 35146 & 13624 & 63.30 \\
\hline Nawabganj & 9679 & 32586 & 22907 & 236.67 \\
\hline Shivpur & 33068 & 33181 & 113 & 0.34 \\
\hline Risia & 28683 & 33875 & 5192 & 18.10 \\
\hline Mahsi & 3361 & 33773 & 30412 & 904.85 \\
\hline Chitaura & 30952 & 32419 & 1467 & 4.74 \\
\hline Tejwapur & 6225 & 33831 & 27606 & 443.47 \\
\hline Fakharpur & 19293 & 32898 & 13605 & 70.52 \\
\hline Huzurpur & 42835 & 33068 & -9767 & -22.80 \\
\hline Bisheshwarganj & 36798 & 34659 & -2139 & -5.81 \\
\hline Payagpur & 33870 & 31696 & -2174 & -6.42 \\
\hline Kaisarganj & 40202 & 34590 & -5612 & -13.96 \\
\hline Jarwal & 47524 & 33887 & -13637 & -28.69 \\
\hline Jamunaha & 41372 & 33006 & -8366 & -20.22 \\
\hline Hariharpur & 30879 & 33006 & 2127 & 6.89 \\
\hline Sirasia & 53410 & 31333 & -22077 & -41.33 \\
\hline Gilaula & 38536 & 33006 & -5530 & -14.35 \\
\hline Ikauna & 11128 & 33006 & 21878 & 196.60 \\
\hline Rupaidih & 52299 & 36477 & -15822 & -30.25 \\
\hline Itia thok & 44489 & 31894 & -12595 & -28.31 \\
\hline Katra Bazar & 33283 & 24409 & -8874 & -26.66 \\
\hline Haldhar Mau & 30563 & 22687 & -7876 & -25.77 \\
\hline Pandri Kripal & 28179 & 20806 & -7373 & -26.16 \\
\hline Mujhana & 28193 & 21460 & -6733 & -23.88 \\
\hline Jhanjhari & 47543 & 33042 & -14501 & -30.50 \\
\hline Colonelganj & 36678 & 26187 & -10491 & -28.60 \\
\hline Paraspur & 30902 & 22950 & -7952 & -25.73 \\
\hline Belsar & 27167 & 20384 & -6783 & -24.97 \\
\hline Tarabganj & 25124 & 19242 & -5882 & -23.41 \\
\hline Wazirganj & 32933 & 23432 & -9501 & -28.85 \\
\hline Mankapur & 55004 & 38065 & -16939 & -30.80 \\
\hline Nawabganj & 35649 & 25911 & -9738 & -27.32 \\
\hline Chhapia & 62221 & 40982 & -21239 & -34.13 \\
\hline Babhanjot & 48229 & 33917 & -14312 & -29.68 \\
\hline Rehra Bazar & 19208 & 28929 & 9721 & 50.61 \\
\hline Gaindas Buzurg & 27527 & 14906 & -12621 & -45.85 \\
\hline Utraula & 34213 & 27639 & -6574 & -19.21 \\
\hline Shridattganj & 36997 & 24531 & -12466 & -33.69 \\
\hline
\end{tabular}


Livestock Husbandry in Devi Patan Plain, Uttar Pradesh: A Geographical Study

\begin{tabular}{|l|c|c|c|c|}
\hline Gainsari & 32526 & 32504 & -22 & -0.07 \\
\hline Pachperwa & 33148 & 32729 & -419 & -1.26 \\
\hline Balrampur & 32437 & 38456 & 6019 & 18.56 \\
\hline Tulsipur & 36523 & 22444 & -14079 & -38.55 \\
\hline Harraiya Satgharwa & 37458 & 37308 & -150 & -0.40 \\
\hline Total & 1490666 & 1332926 & -157740 & -10.58 \\
\hline
\end{tabular}

Source: Statistical Bulletin and District Handbook of the year 1997 and 2007.

Table 7: Block Wise Growth of Sheep in Devi-Patan Plain (1997-98 to 2007-08)

\begin{tabular}{|c|c|c|c|c|}
\hline \multirow[t]{2}{*}{ Development Block } & \multicolumn{2}{|c|}{ Number of Sheep } & \multirow[t]{2}{*}{ Difference } & \multirow[t]{2}{*}{ Growth (in percent) } \\
\hline & $1997-98$ & $2007-08$ & & \\
\hline Mihinpurwa & 4184 & 715 & -3469 & -82.91 \\
\hline Balaha & 1708 & 905 & -803 & -47.01 \\
\hline Nawabganj & 243 & 850 & 607 & 249.79 \\
\hline Shivpur & 2114 & 995 & -1119 & -52.93 \\
\hline Risia & 556 & 705 & 149 & 26.80 \\
\hline Mahsi & 1380 & 1060 & -320 & -23.19 \\
\hline Chitaura & 1185 & 820 & -365 & -30.80 \\
\hline Tejwapur & 1127 & 960 & -167 & -14.82 \\
\hline Fakharpur & 1176 & 1281 & 105 & 8.93 \\
\hline Huzurpur & 466 & 1535 & 1069 & 229.40 \\
\hline Bisheshwarganj & 1372 & 605 & -767 & -55.90 \\
\hline Payagpur & 438 & 735 & 297 & 67.81 \\
\hline Kaisarganj & 466 & 1220 & 754 & 161.80 \\
\hline Jarwal & 503 & 1370 & 867 & 172.37 \\
\hline Jamunaha & 50 & 909 & 859 & 1718.00 \\
\hline Hariharpur & 764 & 909 & 145 & 18.98 \\
\hline Sirasia & 143 & 800 & 657 & 459.44 \\
\hline Gilaula & 377 & 909 & 532 & 141.11 \\
\hline Ikauna & 272 & 909 & 637 & 234.19 \\
\hline Rupaidih & 1694 & 639 & -1055 & -62.28 \\
\hline Itia thok & 1441 & 584 & -857 & -59.47 \\
\hline Katra Bazar & 1078 & 571 & -507 & -47.03 \\
\hline Haldhar Mau & 990 & 563 & -427 & -43.13 \\
\hline Pandri Kripal & 913 & 525 & -388 & -42.50 \\
\hline Mujhana & 913 & 511 & -402 & -44.03 \\
\hline Jhanjhari & 1540 & 651 & -889 & -57.73 \\
\hline Colonelganj & 1188 & 684 & -504 & -42.42 \\
\hline Paraspur & 1001 & 569 & -432 & -43.16 \\
\hline Belsar & 880 & 495 & -385 & -43.75 \\
\hline Tarabganj & 814 & 508 & -306 & -37.59 \\
\hline Wazirganj & 1067 & 610 & -457 & -42.83 \\
\hline Mankapur & 1782 & 695 & -1087 & -61.00 \\
\hline Nawabganj & 1155 & 663 & -492 & -42.60 \\
\hline Chhapia & 2555 & 768 & -1787 & -69.94 \\
\hline Babhanjot & 1562 & 659 & -903 & -57.81 \\
\hline Rehra Bazar & 1111 & 425 & -686 & -61.75 \\
\hline Gaindas Buzurg & 1150 & 301 & -849 & -73.83 \\
\hline Utraula & 1123 & 415 & -708 & -63.05 \\
\hline Shridattganj & 1127 & 410 & -717 & -63.62 \\
\hline Gainsari & 1168 & 829 & -339 & -29.02 \\
\hline Pachperwa & 1090 & 821 & -269 & -24.68 \\
\hline Balrampur & 1149 & 920 & -229 & -19.93 \\
\hline Tulsipur & 1135 & 514 & -621 & -54.71 \\
\hline Harraiya Satgharwa & 1120 & 827 & -293 & -26.16 \\
\hline Total & 49270 & 33349 & -15921 & -32.31 \\
\hline
\end{tabular}

Source: Statistical Bulletin and District Handbook of the year 1997 and 2007.

The total increase in goat during 1997-08 and 2007-08 was 239547 heads. The total growth in Devi Patan plain is 32.74 percent. In terms of block wise variation there is a huge difference between the blocks. The highest growth of goat during the period was found in Gainsari which is at 1860.23 percent. In Jamunaha it is 1014.59 percent, 845.89 percent in Gilaula, 728.68 percent in Ikauna and 911.33 percent growth is found in Sirasia block. The lowest growth was recorded at -36.25 percent in Mihinpurwa block. The other blocks of low growth of goat are Gaindas Buzurg -18.04 percent, Jarwal -8.48 percent, Huzurpur -11.21 percent and -7.62 percent in Fakharpur block. 
Livestock Husbandry in Devi Patan Plain, Uttar Pradesh: A Geographical Study

Table 8: Block Wise Growth of Goat in Devi-Patan Plain (1997-98 to 2007-08)

\begin{tabular}{|c|c|c|c|c|}
\hline \multirow[t]{2}{*}{ Development Block } & \multicolumn{2}{|c|}{ Number of Goat } & \multirow[t]{2}{*}{ Difference } & \multirow[t]{2}{*}{ Growth (in percent) } \\
\hline & $1997-98$ & $2007-08$ & & \\
\hline Mihinpurwa & 47700 & 30410 & -17290 & -36.25 \\
\hline Balaha & 24188 & 29425 & 5237 & 21.65 \\
\hline Nawabganj & 13582 & 31250 & 17668 & 130.08 \\
\hline Shivpur & 25733 & 30725 & 4992 & 19.40 \\
\hline Risia & 23148 & 30915 & 7767 & 33.55 \\
\hline Mahsi & 15570 & 31772 & 16202 & 104.06 \\
\hline Chitaura & 20479 & 31050 & 10571 & 51.62 \\
\hline Tejwapur & 21229 & 30527 & 9298 & 43.80 \\
\hline Fakharpur & 32384 & 29917 & -2467 & -7.62 \\
\hline Huzurpur & 32380 & 28750 & -3630 & -11.21 \\
\hline Bisheshwarganj & 12903 & 29780 & 16877 & 130.80 \\
\hline Payagpur & 9741 & 29988 & 20247 & 207.85 \\
\hline Kaisarganj & 29382 & 31288 & 1906 & 6.49 \\
\hline Jarwal & 34381 & 31464 & -2917 & -8.48 \\
\hline Jamunaha & 2310 & 25747 & 23437 & 1014.59 \\
\hline Hariharpur & 10527 & 25747 & 15220 & 144.58 \\
\hline Sirasia & 2472 & 25000 & 22528 & 911.33 \\
\hline Gilaula & 2722 & 25747 & 23025 & 845.89 \\
\hline Ikauna & 3107 & 25747 & 22640 & 728.68 \\
\hline Rupaidih & 21138 & 20709 & -429 & -2.03 \\
\hline Itia thok & 17981 & 17722 & -259 & -1.44 \\
\hline Katra Bazar & 13452 & 13436 & -16 & -0.12 \\
\hline Haldhar Mau & 12354 & 12397 & 43 & 0.35 \\
\hline Pandri Kripal & 11391 & 11463 & 72 & 0.63 \\
\hline Mujhana & 11398 & 11502 & 104 & 0.91 \\
\hline Jhanjhari & 19216 & 18891 & -325 & -1.69 \\
\hline Colonelganj & 14824 & 14735 & -89 & -0.60 \\
\hline Paraspur & 12491 & 12527 & 36 & 0.29 \\
\hline Belsar & 10981 & 11098 & 117 & 1.07 \\
\hline Tarabganj & 10157 & 12611 & 2454 & 24.16 \\
\hline Wazirganj & 13314 & 13306 & -8 & -0.06 \\
\hline Mankapur & 22236 & 21748 & -488 & -2.19 \\
\hline Nawabganj & 14412 & 14352 & -60 & -0.42 \\
\hline Chhapia & 23752 & 23173 & -579 & -2.44 \\
\hline Babhanjot & 19491 & 19151 & -340 & -1.74 \\
\hline Rehra Bazar & 16346 & 18109 & 1763 & 10.79 \\
\hline Gaindas Buzurg & 12342 & 10115 & -2227 & -18.04 \\
\hline Utraula & 13857 & 17610 & 3753 & 27.08 \\
\hline Shridattganj & 14039 & 17109 & 3070 & 21.87 \\
\hline Gainsari & 1134 & 22229 & 21095 & 1860.23 \\
\hline Pachperwa & 16238 & 22364 & 6126 & 37.73 \\
\hline Balrampur & 16023 & 22199 & 6176 & 38.54 \\
\hline Tulsipur & 14079 & 19201 & 5122 & 36.38 \\
\hline
\end{tabular}




\begin{tabular}{|l|c|c|c|c|}
\hline Harraiya Satgharwa & 15028 & 18153 & 3125 & 20.79 \\
\hline Total & 731612 & 971159 & 239547 & 32.74 \\
\hline
\end{tabular}

Source: Statistical Bulletin and District Handbook of the year 1997 and 2007.

\section{6. Conclusion}

India is one of the largest producers of livestock in the world. Its share in species like buffalo is highest in the world. Livestock is generally reared in those areas, regions and by those farmers who do not have sufficient land, resources to grow crops, and livestock can easily be reared without much effort.

In the study area, the share of buffalo has increased much as compared to other species like goat, sheep and cattle owing to its more demand in the market or household either for milk consumption or meat consumption. In terms of nutrition, quantity and calorie buffalo milk have more nutrition and give more quantity of milk as compared to cattle milk. Due to the opening of several milk industries, dairy industry the demand and production of buffalo has increased. In Devi Patan plain, the share of buffalo has increased in almost all the blocks during the last decade. As far as the population of cattle in the study area is concerned, there is a sharp decline in cattle population during the last decade. The study reveals that there are various reasons which are responsible for the decline of cattle population. Due to the mechanization of agriculture in the study area, the demand of cattle (Male Oxen) has reduced which were used to plough the land, and to transport the grains to the market. With the advent of good transportation facilities the demand of cattle has reduced to a considerable extent. In some cases the Hindus reared cow due to religious practices. Sheep requires a different atmosphere to grow in, it is difficult for the shepherds to go to distant places in pasture land along with their sheep and return back to their home. The production and productivity of wool is also very low and do not give much profit as compared to those who are rearing other livestock species. The population of goat in the blocks of Devi Patan plain have showed that there is an increase in the number of goat in every block of the region. On the occasion of Eid-Ul-Azha every year the demand of goat rises to a considerable extent among the Muslims. During the last decade the growth of goat was about 32 percent.

\section{References}

[1] Iqubal, M.A., (2013). Livestock husbandry and environmental problems, International journal of scientific and research publications, vol. 3, issue 5 .

[2] Khan, N., khan, M.M. and Rehman, A., (2009). Livestock husbandry, rural workforce and employment generation: a case study, The Geographer, vol. 56, No. 2.

[3] Khan, N., \& Iqubal, M.A., (2011). Livestock trade in rural markets of Aligarh district, Journal of Economics and Sustainable Development, vol. 2, No. 8.

[4] Khan, N., \& Iqubal, M.A., (2011). Livestock trade in rural markets of Aligarh district, Journal of Economics and Sustainable Development, vol. 2, No. 8.

[5] Hegde, N.G., (2006). Livestock development for sustainable livelihood of small farmers, Souvenir of the $39^{\text {th }}$ annual general meeting and $48^{\text {th }}$ national symposium on "Energising Rural India - A Challenge to Livestock Industry". Compound Livestock Feed Manufactures Association of India (CLFMA), Manesar, Haryana. pp. 50-63.

[6] Khan, N., Rehman, A. and Salman, S., (2012). Pattern of livestock husbandry in Mahamaya Nagar, the Geographer, vol. 59 , No. 1.

[7] Khan, N., Rehman, A. and Salman, S., (2013). Impact of livestock rearing on the socio-economic development in North India, Forum Geografic, volume XII, issue 1, pp. 75-80.

[8] Ghosh, B., (2012). Livestock Production Management, Bio - Green Books, New Delhi- 110002.

[9] Statistical Bulletin and District Handbook of the year 1997 and 2007. 